\title{
Scientific and Methodological Approach to the Rating of Organizations of the Russian Military-Industrial Complex Developing Civilian Manufacturing
}

\author{
Tatyana A. Berkutova ${ }^{1 *[O R C I D ~ 0000-0003-3357-7845], ~}$ \\ Alexander A. Zgruev 2[ORCID 0000-0002-7039-7678], \\ Denis A. Zhurenkov 1[ORCID 0000-0002-3968-5815]
}

\author{
${ }^{I}$ All-Russia Scientific and Research Institute "Center", Moscow, Russia \\ ${ }^{2}$ Ministry of Industry and Trade of the Russian Federation, Moscow, Russia \\ tberkutova@yandex.ru
}

\begin{abstract}
The purpose of the study is to develop a scientific and methodological approach to rating the enterprises of the military-industrial complex of Russia in the course of the development of civilian production and the development of markets for high-tech products of dual and civilian use. The results of the study of scientific works and investment projects on entering the markets of civilian products of enterprises of the militaryindustrial complex made it possible to form the structure of their rating in the composition of five profiles and the criteria and assessment indicators included in them. The profiles include: financial and economic profile, diversification profile, organizational development dynamics, marketing profile, management profile. In the course of the study, the choice was substantiated for using in the course of rating indicators for assessing the effectiveness and efficiency of enterprises of the military-industrial complex in the process of developing civilian markets. Within each profile, methods for calculating the constituent indicators were proposed, scales were developed for each indicator, the proposed indicators were combined into a single rating system. The proposed scientific and methodological approach makes it possible to combine individual indicators characterizing the achievements in the markets of civilian and dual products into a structured system of profiles, which allows, on the basis of integration, to determine the total rating of organizations of the military-industrial complex, as well as to carry out their comparative analysis. The developed rating model makes it possible to monitor, analyze and evaluate the work of organizations of the military-industrial complex, on their basis to form targeted measures to support organizations, to develop and enforce regulations, projects and programs that stimulate the development of the military-industrial complex in civilian markets. Within the framework of the proposed model, a multilevel approach to rating has been implemented, taking into account the corporate, industry and state levels.
\end{abstract}

Keywords: rating of organizations, military-industrial complex, dual-use and civilian products, diversification

\section{INTRODUCTION}

At present, the Russian military-industrial complex (hereinafter - MIC) has a strategic task to increase the production of high-tech civilian and dualuse products (hereinafter - HTCDP) to $50 \%$ by 2030 .

As observed in the course of solving the problem, the different dynamics of the indicators of the production of HTCDP in different industries indicates a significant differentiation in the results of the development of civilian markets.

At the same time, at the state level, measures are being actively taken to support the processes of entering the HTCDP markets: improving the regulatory and methodological framework, implementing measures to support defense industry 
enterprises, developing interaction mechanisms in the process of developing civilian markets.

In this situation, it is necessary to develop methods and tools that allow for a more reasonable and targeted approach to stimulating the processes of developing the HTCDP markets in the MIC, to increase the reliability of the quantitative and qualitative assessment of the results of work in the markets, and to manage the development of civilian production in the MIC within the framework of a single digital platform. Rating is an effective tool for solving the listed tasks.

Domestic and foreign scientists are engaged in the study of the problems of assessing the work of MIC organizations in the HTCDP markets. A number of authors consider the financial results of work in the markets as a priority [1-3], other authors consider the innovation component, the possibility of developing new technologies and products [4-6]. The formation of modern business models, an increase in the adaptability, mobility, and efficiency of MIC enterprises as a result of the development of civil markets and diversification is noted by the majority of researchers [7-11].

Despite a significant number of developments on the issues of assessing the performance of MIC organizations in the HTCDP markets, there is a lack of scientific and methodological approaches in the field of integrated assessment, combining financial and economic, market, innovation, institutional and other components.

As part of solving the scientific problem of developing a methodological approach to rating MIC organizations, the article considers:

- components of a comprehensive assessment of the results of market activities for MIC organizations used in determining the rating;

- selection and methods of formation of indicators for assessing market activity;

- scaling of indicators used in the course of rating.

\section{MATERIALS AND METHODS}

Ranking is positioning MIC organizations in accordance with the achieved results of their activities in the HTCDP markets, determined on the basis of the assessment.

Purpose of the study: development of a scientific and methodological approach to the rating of MIC enterprises in the process of developing the HTCDP markets.

Research objectives:

- determination of the components of the rating - indicators of the assessment of MIC organizations in accordance with the results achieved in the HTCDP markets;

- substantiation of the composition of assessment indicators included in the rating system;

- selection of methods for determining the values of assessment indicators used in determining the rating;

- formation of rating scales for indicators used in the rating system.

In this study, the rating is assigned to the MIC organization as a system, and not to its individual subdivisions, and is a complex discrete characteristic of its activities.

The research methodology is determined by a set of scientific methods, as well as the goal, objectives and principles of rating, methods of researching business models and market activities of MIC organizations, and the principles of diversification.

The methodological basis of the study was the scientific work of Russian and foreign scientists on the strategic development and diversification of the MIC, research of methods, indicators and criteria for assessing the effectiveness and efficiency of activities in the development of HTCDP markets and their impact on the economic activity of the enterprise.

In the course of the study, a systematic and integrated approach, methods of financial and economic, comparative and factor analyzes were used. In the course of the study, the factors of the internal and external environment that determine the effectiveness of market activity were identified, the issues of the formation of complex and single indicators for assessing MIC organizations were investigated.

\section{RESULTS}

\subsection{Determination of the goals and objectives for the rating}

As a result of the analysis of various sources, the goals and objectives for rating the MIC organizations were formulated. 
The purpose of the rating: management and coordination of the development processes for civilian production at MIC enterprises.

Rating tasks:

- assessment of the state of the development processes of civilian industries in MIC organizations;

- assessment of the breadth and nomenclature of the HTCDP assortment;

- comparative assessment of defense industry organizations in the course of diversification;

- differentiation of measures and tools for intensifying the processes of development of civilian industries for defense industry organizations in different rating groups;

- assessment of the dynamics of the development of HTCDP production in the MIC.

Rating object: MIC organizations.

Rating subject: mechanisms for the development of civilian production of organizations in the Russian MIC.

\subsection{A systematic approach to building the overall rating structure}

On the basis of a comprehensive analysis of the goals and objectives of activities for the development of civilian industries [7, 8, 11-14], the authors of this work proposed a structure of the directions of activity for the MIC enterprises, used for rating, in which the rating is determined on the basis of the values of indicators combined into five main blocks - profiles (Figure 1).

The final rating score is formed on the basis of point scores for the given blocks. In addition, to be assigned a specific rating, an organization must meet a set of mandatory requirements.

The aggregate of points of all weights of the blocks of this rating is 100 points. Each of the five main blocks has its own internal weight. Each factor has its own answer options, scores of indicators vary in the range from 0 to 10 points. Thus, the minimum score for the rating profile is 0 points, and the maximum score is 50 points.

The grouping of indicators that form the rating profiles was carried out on the basis of systematization of the goals and objectives of the activities for the development of the HTCDP markets $[1,4,5,8,11,15]$.

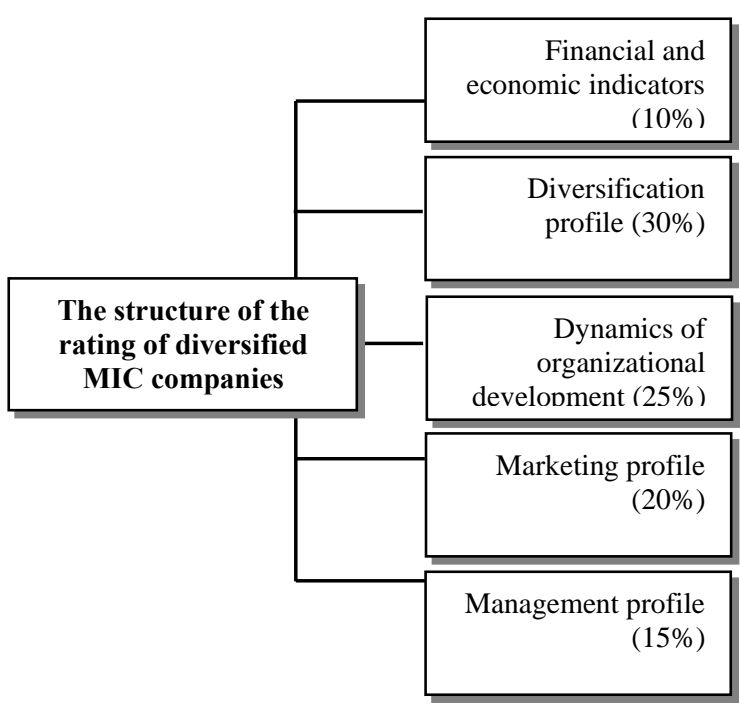

Figure 1. The structure of the rating of MIC organizations in the context of the development of civilian industries

Source: Compiled by the authors

The following initial information is used for rating:

- statistical reporting of MIC organizations;

- reports submitted to the tax service by MIC organizations;

- information provided by MIC organizations to All-Russia Scientific and Research Institute "Center" (reporting within the framework of monthly monitoring of priority projects/programs, data provided as part of a questionnaire survey of MIC organizations).

\subsection{Determination of indicators - components of the rating for MIC organizations}

To determine the rating of the financial and economic state of the MIC organizations (hereinafter - RFES), a set of algorithms for assigning an individual rating to an enterprise based on an assessment of 11 quantitative factors and 2 warning signals is considered. The maximum number of points for the profile of the organization's financial and economic indicators is 10 points.

In this model of rating the financial condition of organizations, quantitative indicators are used, as well as warning signals.

In this model of rating the financial condition of organizations, quantitative indicators are used, as well as warning signals.

Quantitative indicators of the financial and economic profile: 
- financial independence and stability ratios;

- the degree of solvency for current obligations;

- the coefficient of provision with own circulating assets;

- absolute and current liquidity ratios;

- return on sales based on net profit;

- return on assets;

- the estimated value of net assets and their comparison with the authorized capital;

- debt/EBITDA ratio;

- the share of overdue debt on payments to the budget from equity capital.

Determination of the estimated rating for 11 quantitative indicators $\left(\right.$ RFES $\left._{\mathrm{i}}\right)$ is carried out based on the ranges of values of indicators. The ranges of values are arranged in values from 1 to 3 with a step of 0.1 to further assign a point rating to the MIC organization. The preliminary rating is determined by the formula (1):

$$
R F E S_{\Pi}=\frac{\sum R F E S_{i} \times W_{i}}{100 \%}
$$

where $\mathrm{RFES}_{\Pi}$ - a preliminary rating; $\mathrm{RFES}_{\mathrm{i}}$ - the estimated rating for the indicator number $\mathrm{i} ; \mathrm{W}_{\mathrm{i}}-$ the weighting factor of the indicator.

The preliminary rating is adjusted in the presence of warning signals, which include: the presence of overdue wage arrears to staff, the introduction of bankruptcy procedures. In this case, the organization is assigned an estimated rating of " 3 ".

Based on the preliminary $\operatorname{RFES}_{\Pi}$ and its adjustments, the RFES of each organization is determined. Organization points are awarded based on the range of the RFES (Table 1).

Table 1. Determination of the level of the financial and economic condition of the organization

\begin{tabular}{|l|c|c|c|c|c|c|c|c|c|c|}
\hline $\begin{array}{l}\text { Rating of Financial and Economic } \\
\text { Indicators of the MIC Organization }\end{array}$ & $\begin{array}{c}1.0- \\
1.1\end{array}$ & $\begin{array}{c}1.2- \\
1.3\end{array}$ & $\begin{array}{c}1.4- \\
1.5\end{array}$ & $\begin{array}{c}1.6- \\
1.7\end{array}$ & $\begin{array}{c}1.8- \\
1.9\end{array}$ & $\begin{array}{c}2.0- \\
2.1\end{array}$ & $\begin{array}{c}2.2- \\
2.3\end{array}$ & $\begin{array}{c}2.4- \\
2.5\end{array}$ & $\begin{array}{c}2.6- \\
2.7\end{array}$ & $\begin{array}{c}2.8- \\
3.0\end{array}$ \\
\hline Points & 10 & 9 & 8 & 7 & 6 & 5 & 4 & 3 & 2 & 1 \\
\hline
\end{tabular}

Source: Compiled by the authors

The assessment of the diversification profile of the MIC organization is based on the assessment of the indicators presented in the table (Table 2).

The estimated rating of the diversification profile is determined by the formula (2):

$$
R D P_{\mathrm{o}}=\sum R D P_{\mathrm{i}}
$$

where $\mathrm{RDP}_{\mathrm{o}}-$ the rating of the diversification profile of the MIC organization; RDPi - an indicator of the diversification profile of a MIC organization.

Diversification profile metrics are scored on a scale from zero to five. The maximum rating for the diversification rating of a MIC organization is 30 points. The determination of the $\mathrm{RDP}_{\mathrm{o}}$ is carried out on the basis of the point values of the qualitative indicators (Table 2).

Table 2. The point values of the qualitative indicators of the rating of the diversification profile of the MIC

\begin{tabular}{|c|c|c|c|c|c|c|}
\hline \multirow{2}{*}{ Indicator } & \multicolumn{6}{|c|}{ Points } \\
\hline & 5 & 4 & 3 & 2 & 1 & 0 \\
\hline Export deliveries (\% of the issue of HTCDP for the year) & $>15 \%$ & $11-14 \%$ & $6-10 \%$ & $1-5 \%$ & $0-0.9 \%$ & $\begin{array}{l}\text { No export } \\
\text { deliveries }\end{array}$ \\
\hline $\begin{array}{l}\text { Compliance of products with the development priorities of the } \\
\text { state (national projects and programs, plans for import } \\
\text { substitution) }\end{array}$ & $>5$ & $4-5$ & 3 & 2 & 1 & 0 \\
\hline Number of product items included in the Catalog & $>100$ & $50-100$ & $30-49$ & $10-29$ & $<10$ & No items \\
\hline $\begin{array}{l}\text { Dynamics of the implemented investment projects for the } \\
\text { release of HTCDP (increase in the number of projects per } \\
\text { year) }\end{array}$ & $>10$ & $7-10$ & $3-6$ & $1-3$ & 0 & $\begin{array}{l}\text { Negative } \\
\text { dynamics } \\
\text { (exclusion } \\
\text { of projects) }\end{array}$ \\
\hline $\begin{array}{l}\text { Volume of HTCDP output covered by projects / products } \\
\text { included in the Register of Diversification Projects }\end{array}$ & $\begin{array}{c}80- \\
100 \%\end{array}$ & $60-79 \%$ & $40-59 \%$ & $20-39 \%$ & $0-19 \%$ & $\begin{array}{l}\text { No projects } \\
\text { / products }\end{array}$ \\
\hline $\begin{array}{l}\text { Experience in implementing projects involving budget funds, } \\
\text { incl. within the framework of subsidiary support, support for } \\
\text { development institutions, etc. / the existence of partnerships } \\
\text { and (or) joint projects with the participation of industrial and } \\
\text { other clusters / industrial parks / engineering centers }\end{array}$ & $>9$ & 7-8 & $5-6$ & $3-4$ & $1-2$ & No projects \\
\hline
\end{tabular}
organization

Source: Compiled by the authors 
The assessment of the profile of the dynamics of the development of the MIC organization characterizes the position of the organization in the industry and in the region (federal district, constituent entity of the Russian Federation) and is carried out on the basis of an assessment of deviations in growth (decline) rates from similar indicators of the industry / region.

Indicators for assessing the dynamics of the development of the MIC organization are presented in Table 3.

The estimated rating of the profile of the dynamics of the development of the MIC organization is determined by the formula (3):

$$
R D D O_{\mathrm{o}}=\sum R D D O_{\mathrm{i}}
$$

where $\mathrm{RDDO}_{\mathrm{o}}$ - the rating of the profile of the dynamics of the development of the MIC organization; $\mathrm{RDDO}_{\mathrm{i}}$ - an indicator of the dynamics of the development of the MIC organization.

The indicators of the profile of the dynamics of the development of the MIC organization are assessed in points on a scale from 0 to 5 . The maximum rating for this profile is 25 points. The determination of the $\mathrm{RDDO}_{\mathrm{o}}$ rating is carried out based on the point values of quantitative indicators (Table 3).

Table 3. The point values of the quantitative indicators of the rating of the dynamics of the development of the MIC organization

\begin{tabular}{|c|c|c|c|c|c|c|}
\hline \multirow{2}{*}{ Indicator } & \multicolumn{6}{|c|}{ Points } \\
\hline & 5 & 4 & 3 & 2 & 1 & 0 \\
\hline $\begin{array}{l}\text { Leading (lagging) growth rates in } \\
\text { the Federal District (by industry) }\end{array}$ & $>2 \mathrm{pp}$ & 1-2 pp. & 0.05-0.9 pp. & 0.01-0.05 pp. & 0 pp. & $\begin{array}{l}<0 \text { п.п. } \\
\text { (slowdown } \\
\text { in growth) }\end{array}$ \\
\hline $\begin{array}{l}\text { Leading (lagging) growth rates in } \\
\text { the constituent entity of the Russian } \\
\text { Federation (by industry) }\end{array}$ & $>2 \mathrm{pp}$ & 1-2 pp. & 0.05-0.9 pp. & 0.01-0.05 pp. & 0 pp. & $\begin{array}{l}<0 \text { п.п. } \\
\text { (slowdown } \\
\text { in growth) }\end{array}$ \\
\hline $\begin{array}{l}\text { Leading (lagging) growth rates in } \\
\text { the defense industry }\end{array}$ & $>2$ pp. & 1-2 pp. & 0.05-0.9 pp. & 0.01-0.05 pp. & 0 pp. & $\begin{array}{l}<0 \text { п.п. } \\
\text { (slowdown } \\
\text { in growth) }\end{array}$ \\
\hline Share of HTCDP in total output & $>50 \%$ & $30-49.9 \%$ & $15-29.9 \%$ & $10-14.9 \%$ & $5-9.9 \%$ & $<4.9 \%$ \\
\hline \multirow{2}{*}{$\begin{array}{l}\text { Contribution to the actual output of } \\
\text { the industry's HTCDP }\end{array}$} & \multicolumn{5}{|c|}{$\begin{array}{l}\text { Assessment of changes in output volumes (to the previous reporting } \\
\text { period) - growth: }\end{array}$} & \multirow{2}{*}{$\begin{array}{l}\text { Negative } \\
\text { dynamics }\end{array}$} \\
\hline & $\begin{array}{l}\text { more than } \\
2 \text { pp. }\end{array}$ & $\begin{array}{l}\text { more than } \\
1 \text { pp. }\end{array}$ & $\begin{array}{l}\text { more than } \\
0.05 \mathrm{pp} \text {. }\end{array}$ & $0.01-0.05$ pp. & 0-0.01 pp. & \\
\hline
\end{tabular}

Source: Compiled by the authors

The assessment of the marketing profile of a MIC organization characterizes the assessment of prospects in the markets of presence, the organization's position in these markets, product promotion channels and customer service.

Metrics for evaluating the marketing profile are presented in Table 4.

The estimated rating of the marketing profile is determined by the formula (4):

$$
\mathrm{RPM}_{\mathrm{o}}=\Sigma \mathrm{RPMi},
$$

where $\mathrm{RPM}_{\mathrm{o}}$ - the rating of the marketing profile of the defense industry organization; $\mathrm{RPM}_{\mathrm{i}}-$ an indicator of the marketing profile of a MIC organization.

The indicators are rated on a scale of 0 to 6 and 8 points. The maximum rating of the marketing profile of a defense industry organization is 20 points.

The determination of the RPMi rating is carried out on the basis of the point values of qualitative indicators (Table 4).

\begin{tabular}{|c|c|c|c|c|c|c|}
\hline \multirow{2}{*}{$\begin{array}{c}\text { Indica- } \\
\text { tors }\end{array}$} & \multicolumn{6}{|c|}{ Points } \\
\hline & 6 & 4.8 & 3.6 & 2.4 & 1.2 & 0 \\
\hline 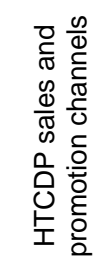 & $\begin{array}{l}\text { Own IT } \\
\text { platform for } \\
\text { product } \\
\text { promotion } \\
\text { and } \\
\text { customer } \\
\text { service }\end{array}$ & $\begin{array}{l}\text { Promotion of } \\
\text { products through } \\
\text { the tools of } \\
\text { Internet services } \\
\text { / through the } \\
\text { networks of } \\
\text { dealerships }\end{array}$ & $\begin{array}{l}\text { The use of } \\
\text { traditional } \\
\text { advertising tools } \\
\text { / products are } \\
\text { presented on the } \\
\text { GISP site }\end{array}$ & $\begin{array}{l}\text { Participation in fair and } \\
\text { exhibition events / } \\
\text { advertising in highly } \\
\text { specialized publications } \\
\text { / availability of } \\
\text { information about } \\
\text { products on the } \\
\text { organization's website }\end{array}$ & $\begin{array}{l}\text { Direct sales in } \\
\text { the absence of } \\
\text { promotional } \\
\text { activities }\end{array}$ & $\begin{array}{l}\text { Lack of } \\
\text { promotional } \\
\text { activities, } \\
\text { direct sales }\end{array}$ \\
\hline
\end{tabular}

Table 4. The point values of the qualitative indicators of the marketing profile of the MIC organization 


\begin{tabular}{|c|c|c|c|c|c|c|}
\hline \multirow{2}{*}{$\begin{array}{l}\text { Indica- } \\
\text { tors }\end{array}$} & \multicolumn{6}{|c|}{ Points } \\
\hline & 6 & 4.8 & 3.6 & 2.4 & 1.2 & 0 \\
\hline 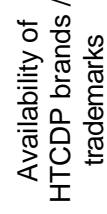 & $\begin{array}{l}\text { More than } 5 \\
\text { brands / } \\
\text { trade marks }\end{array}$ & $\begin{array}{l}4-5 \text { brands / } \\
\text { trademarks }\end{array}$ & $\begin{array}{l}3 \text { brands / } \\
\text { trademarks }\end{array}$ & 2 brands / trademarks & $\begin{array}{c}1 \text { brand / } \\
\text { trademark }\end{array}$ & $\begin{array}{l}\text { No brands } \\
\text { trademarks }\end{array}$ \\
\hline 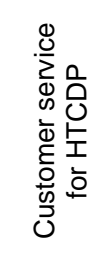 & $\begin{array}{c}\text { Service } \\
\text { center } \\
\text { network, } \\
\text { international } \\
\text { delivery } \\
\text { services }\end{array}$ & $\begin{array}{l}\text { Availability of } \\
\text { service and } \\
\text { warranty } \\
\text { service, delivery } \\
\text { of HTCDP } \\
\text { throughout the } \\
\text { country }\end{array}$ & $\begin{array}{l}\text { Availability of } \\
\text { service and } \\
\text { warranty } \\
\text { service, delivery } \\
\text { of HTCDP in the } \\
\text { territory of the } \\
\text { constituent entity } \\
\text { of Russia }\end{array}$ & $\begin{array}{l}\text { Availability of service on } \\
\text { the basis of the } \\
\text { organization }\end{array}$ & $\begin{array}{l}\text { Service is not } \\
\text { established / } \\
\text { not } \\
\text { standardized / } \\
\text { are not } \\
\text { provided on an } \\
\text { ongoing basis }\end{array}$ & $\begin{array}{l}\text { No after- } \\
\text { sales } \\
\text { service and } \\
\text { no service } \\
\text { available }\end{array}$ \\
\hline
\end{tabular}

Source: Compiled by the authors

In this profile, indicators of the effectiveness and efficiency of management are formed and systematized (Table 5).

The estimated rating of the management profile is determined by the formula (5):

$$
R M P_{\mathrm{o}}=\sum R M P_{i}
$$

where $\mathrm{RMP}_{\mathrm{o}}$ - the rating of the management profile of the MIC organization; $\mathrm{RMP}_{\mathrm{i}}-$ an indicator of the management profile of the MIC organization.

Indicators are assessed on a scale from 0 to 3 and 4 points, depending on the indicator. The maximum rating of the management profile of a MIC organization is 15 points (Table 5).

Table 5. The point values of the qualitative indicators of the rating of the management profile of the MIC organization

\begin{tabular}{|c|c|c|c|c|c|c|}
\hline \multirow{2}{*}{ Indicators } & \multicolumn{6}{|c|}{ Points } \\
\hline & 4 & 3.2 & 2.4 & 1.6 & 0.8 & 0 \\
\hline $\begin{array}{l}\text { Average output per } 1 \text { employee (average } \\
\text { annual, assessment of dynamics) }\end{array}$ & $\begin{array}{l}+4 \% \text { and } \\
\text { more }\end{array}$ & $+3 \%$ & $+2 \%$ & $+1 \%$ & 0 & $\begin{array}{l}\text { Negative } \\
\text { dynamics }\end{array}$ \\
\hline $\begin{array}{l}\text { Average salary of personnel (assessment } \\
\text { of dynamics to the previous reporting } \\
\text { period in the constituent entity of the } \\
\text { Russian Federation) }\end{array}$ & $\begin{array}{l}4.6 \text { and } \\
\text { more } \%\end{array}$ & $4.26-4.5$ & $4.01-4.25$ & $4 \%$ & $2-3 \%$ & $\begin{array}{l}\text { Less than } \\
2 \% \text { and } \\
\text { negative } \\
\text { dynamics }\end{array}$ \\
\hline $\begin{array}{l}\text { Availability of scholarships for outstanding } \\
\text { achievements in MIC }\end{array}$ & $\begin{array}{l}5 \text { and } \\
\text { more }\end{array}$ & 4 & 3 & 2 & 1 & 0 \\
\hline Point Indicator & \multicolumn{2}{|c|}{$\frac{1}{3}$} & \multicolumn{2}{|c|}{1.8} & \multicolumn{2}{|c|}{0} \\
\hline $\begin{array}{l}\text { Complete presentation of information in } \\
\text { the specialized information resources of } \\
\text { the Ministry of Industry and Trade of } \\
\text { Russia }\end{array}$ & \multicolumn{2}{|c|}{$\begin{array}{l}\text { Full posting of } \\
\text { information in the } \\
\text { personal account } \\
\text { "Register of projects } \\
\text { (programs) of the } \\
\text { production of HTCDP" }\end{array}$} & \multicolumn{2}{|c|}{$\begin{array}{l}\text { Incomplete posting of } \\
\text { information in the } \\
\text { personal account } \\
\text { "Register of projects } \\
\text { (programs) for the } \\
\text { production of HTCDP" }\end{array}$} & \multicolumn{2}{|c|}{ Information not provided } \\
\hline
\end{tabular}

Source: Compiled by the authors

The final rating score is the sum of the scores for the given blocks (6):

$$
\begin{gathered}
R_{f}=R F E S+R D P_{\mathrm{o}}+R D D O_{\mathrm{o}}+ \\
+R P M_{\mathrm{o}}+R M P_{\mathrm{o}}
\end{gathered}
$$

The maximum possible score is 10 .

\section{DISCUSSION}

The developed scientific and methodological approach differs from the existing ones in complexity, and takes into account the achievements of the MIC organization in the process of developing civilian markets from the standpoint of financial condition, management efficiency, development of strategic directions of activity and work with the market.

The scientific approaches presented in various publications consider the assessment of the results of market activity in the defense industry from various points of view.

The most common criteria and indicators of performance and efficiency are financial and economic [1-3].

The development and production of a new 
HTCDP in the course of the development of civilian MIC markets, the assessment of the product portfolio indicators (breadth and depth of the product line, the dynamics of new products in new and already developed markets, product innovations) is considered in a number of publications [4-6, 12] in the context of increasing innovative activity, technology transfer and civil-military integration, the effectiveness of research and development work in the MIC [2, 4, 5, 8-10].

The systematization of market activity in the process of diversification is considered within the framework of marketing approaches and mechanisms $[8,10,16]$.

Evaluation of the activities of MIC organizations in the HTCDP markets based on management results is considered in the works of the authors [7-9, 11, 12], where the need to form market strategies, business value, its investment attractiveness and efficiency in the HTCDP markets is noted.

The effectiveness of partnerships, the development of institutional instruments in the process of entering new markets is considered in works $[8,11,13,15]$.

\section{CONCLUSION}

The novelty of the proposed approach consists in the combination of individual indicators characterizing the activities of MIC organizations in the development of civilian industries into a structured system of profiles. This allows, on the basis of integration, to determine the total rating of MIC organizations, as well as to carry out their comparative analysis within the framework of a multilevel approach (from the standpoint of corporate, sectoral and state levels).

\section{AUTHORS' CONTRIBUTIONS}

The authors made an equal contribution to the study: collection and analysis of material; definition of goals and objectives, research methods; formulation and scientific substantiation of conclusions, registration of key research results in the form of an article.

\section{REFERENCES}

[1] A.M. Batkovskii, N.I. Turko, A.V. Fomina, "Controlling of the diversification of the militaryindustrial complex enterprises", Controlling, 2020, vol. 1(75), pp. 2-11. (In Russ.).
[2] N.A. Budarina, Yu.A. Basalaeva, "Diversification of the Russian helicopters holding as one of the ways to increase the foreign economic potential", Economy and Business: Theory and Practice, 2021, vol. 31(73), pp. 97-101. (In Russ.). DOI: 10.24412/2411-0450-2021-3-1-97-101

[3] E. Dyundik, S. Golubev, A. Makhova, L. Gurtskoy, "Development of human capital in the military industrial complex of Russia in the context of digital transformation", in Proceedings of the ISPC "Environmental Risks and Safety in Mechanical Engineering", E3s Web Conf., 2020, vol. 217. DOI: $10.1051 / \mathrm{e} 3$ sconf/202021706005

[4] A.M. Batkovskiy, M.A. Batkovskiy, E.Yu. Khrustalev, "Evaluation of scientific research and development works providing diversification of production", Actual Problems of Economics and Law, 2021, vol. 15(1), pp. 3142. (In Russ.). DOI: 10.21202/1993047X.15.2021.1.31-42

[5] A.N. Link, J.T. Scott, "The Economic Benefits of Technology Transfer from U.S. Federal Laboratories", UNC Greensboro Department of Economics Working Paper Series, 2019, Working Paper 19-06.

[6] B.O. Martins, N. Ahmad, "The security politics of innovation: Dual-use technology in the EU's security research programme", In Eds. by A. Calcara, R. Csernatoni, C. Lavallŭе, "Emerging Security Technologies and EU Governance Actors, Practices and Processes", London: Routledge, 2020.

[7] V.V. Pimenov, "On the change in the business model of the development of the defense industry enterprises during the transition to a new state armaments program" [Ob izmenenii biznes-modeli razvitiya predpriyatiy oboronnopromyshlennogo kompleksa pri perekhode $\mathrm{k}$ novoy gosudarstvennoy programme vooruzheniy], in Proceedings of the Militaryeconomic Development in the Light of Global Transformations, Moscow: IMEMO, 2019, pp. 60-63. (In Russ.).

[8] T.A. Berkutova, "Indicators of assessment of diversification efficiency for the enterprises of the defense industrial complex", Vestnik IzhGTU imeni M.T. Kalashnikova, 2018, vol. 21(3), pp. 136-141. (In Russ.). DOI: 10.22213/2413-1172-2018-3-136-141 
[9] O. Gassmann, K. Frankenberger, R. Sauer, "Exploring the Field of Business Model Innovation", Publisher Name: Palgrave Macmillan, Cham, 2016.

[10] Ph. Kotler, H. Kartajaya, I. Setyawan, "Marketing 4.0: Moving from Traditional to Digital", Kindle Edition, 2016.

[11] S.V. Chemezov, N.I. Turko, S.A. Kulikov, P.A. Drogovoz, "Problems of strategic management of the processes of military-civil integration in high-tech industries of the Russian Federation", in Problems of Strategic Management and Mechanisms of Military-civil Integration in High-Tech Industries: Collection of Articles, Moscow: TsOP AVN, 2011, pp. 522. (In Russ.).

[12] S.I. Dovguchits, D.A. Zhurenkov, "Problems of diversification of the military-industrial complex and ways of their solutions", Scientific Bulletin of the Military-Industrial Complex of Russia, 2017, vol. 4, pp. 7-17. (In Russ.).
[13] Catalytic Converter Market Global Forecast to 2021, 2021. Retrieved from www.marketsandmarkets.com/PressReleases/cat alytic-converter-systems

[14] A. Gollay, "Strategic Development Managment of Industrial Enterprises from the Perspective of a Degree Perfection Increase of Technival Systems", Bulletin of the South Ural State University. Ser. Computer Technologies, Automatic Control, Radio Electronics, 2017, vol. 17, pp. 158-158.

[15] V.F. Protashchik, A.A. Rodriguez Pendas, D.A. Zhurenkov, "Actualization of approaches to developing a diversification strategy in DIC", Scientific Bulletin of the Military-Industrial Complex of Russia, 2020, vol. 1, pp. 34-48. (In Russ.).

[16] M.E. Porter, J.E. Heppelmann, "Why Every Organization Needs an Augmented Reality Strategy", Harvard Business Review, 2017, pp. 46-62. 